\title{
POSSE DE ARMA DE FOGO: POSSIBILIDADE DE ABOLITIO CRIMINIS A PARTIR DA SUCESSÁO DE NORMA DE COMPLEMENTAÇÃO DE LEI PENAL EM BRANCO NO TEMPO
}

\author{
Tarcísio Chaves Mendonça ${ }^{1}$ \\ Escola Superior Dom Helder Câmara (ESDHC)
}

Artigo recebido em: 08/04/2019

Artigo aceito em: 18/06/2019

\section{Resumo}

O presente artigo teve como objetivo

elemento em branco, diferenciandoavaliar se a nova redaçáo dada ao art. 16 , $\$ 2^{\circ}$, do Decreto n. 5.123/2003 -o do normativo jurídico. Após, será analisada cada uma das teorias que buscam enfrentar o problema. Ao final, conclui-se que a teoria que melhor explica o problema é a diferenciadora; para ser mais específico, a teoria da alteraçáo dos dados fáticos. Ela justifica a restrição da abolitio criminis nos casos de sucessão de norma de complementaçáo de lei penal em branco no tempo a partir do princípio da isonomia. Será utilizado o método hipotético dedutivo

Palavras-chaves: posse de arma; lei penal em branco; norma de complementação; abolitio criminis.

1 Doutor em Direito e Mestre em Ciências Penais pela UFMG. Professor de Direito e Processo Penal na Faculdade Dom Helder Câmara. Advogado criminalista. E-mail: tarcisio@mrladvocacia.com.br 


\section{FIREARMS POSSESSION: POSSIBILITY OF THE ABOLITIO CRIMINIS FROM THE SUCCESSION OF A COMPLEMENTATION NORM OF IN WHITE PENAL LAW IN TIME}

\section{Abstract}

The purpose of this paper is to evaluate whether the new composition given to art. 16, paragraph 2 of Executive Order n. 5,123/2003 by Executive Order n. 9,685/2019 has the effect of provoking, in relation to the perpetrators of the crime described in art. 12 of Law $n$. $10,826 / 2003$, the extinction of punishment by the abolitio criminis. The art. 12 of Law n. 10,826/2003 is a "vague" criminal law (or as it is called in Portuguese: in white penal law). Executive orders n. 5,123/2003 and n. 9,685/2019 are its complement norms. The question is to establish the criteria to define the width of the abolitio criminis when the succession in time of a norm that comes to complement a vague (in white) penal law occurs. It is important to define well the limits of the vague (in white) element, distinguishing it from the normative element. Afterwards, the research analyzed each one of the theories which faces the problem. In the end, the conclusion reached was that the theory that best explains the problem is the differentiating type; to be more specific, the theory of factual data alteration. This theory justifies the restriction of the abolitio criminis in cases of succession of complementation norm of a vague (in white) law in time based on the principle of isonomy. The hypothetical deductive method will be used.

Keywords: firearm possession; vague (in white) penal law; norm of complementation; abolitio criminis.

\section{Introduçáo}

O presente artigo tem como objetivo avaliar a incidência da abolitio criminis na sucessão de norma de complementação de lei penal em branco no tempo. Avaliaremos se a nova redação dada ao art. $16, \$ 2^{\circ}$, do Decreto n. 5.123/2003 pelo Decreto n. 9.685/2019 tem o efeito de provocar, em relação aos autores do crime descrito no art. 12 da Lei n. 10.826/2003, a extinção da punibilidade.

$\mathrm{O}$ tema consiste em avaliar se o princípio da anterioridade, em matéria penal, também se aplica ao conflito, no tempo, de norma de complementação de lei penal em branco. $\mathrm{O}$ assunto é denso e muito pouco explorado pela doutrina nacional e estrangeira. Na doutrina alienígena, é digno de nota o trabalho de Gian Luigi Gatta (2008), cujo título é Abolitio Criminis e successione di norme integratrici: teoria e prassi. 
Em nossos Tribunais, o assunto também não foi discutido com a merecida verticalização. O tema já é conhecido da Suprema Corte desde a década de 50, por conta dos nossos sucessivos planos econômicos, ocorridos no último século. O Superior Tribunal de Justiça já se debruçou sobre a amplitude da abolitio criminis na sucessáo de norma de complementação de lei penal em branco. Enfrentou o tema ao tratar do crime descrito no art. 90 da Lei n. 8.666/90 e na Lei n. 8.176/91, entre outras hipóteses. Todavia, não há o registro de um voto que delimite o conceito de lei penal em branco. Não se diferencia elemento em branco do normativo. Não conhecemos um só julgado que analisa a natureza da norma de complementação: pressuposto de aplicação da lei penal ou parte que a integra. A exemplo da doutrina, a jurisprudência também é pobre em reflexóes sobre o tema, objeto do presente artigo.

O problema a ser analisado centra-se no tipo penal descrito no art. 12 da Lei n. 10.826/2003 que é assim descrito:

\section{Possuir ou manter sob sua guarda arma de fogo, acessório ou mu- nição, de uso permitido, em desacordo com determinaçáo legal ou regulamentar, no interior de sua residência ou dependência desta, ou, ainda no seu local de trabalho, desde que seja o titular ou o responsável legal do estabelecimento ou empresa (BRASIL, 2003).}

Para que se possa, licitamente, possuir ou manter uma arma de fogo, acessório ou munição, de uso permitido, o proprietário deverá ter um Certificado de Registro de Arma de Fogo. Esse certificado tem prazo de validade e autoriza o "proprietário a manter a arma de fogo exclusivamente no interior de sua residência ou domicílio, ou dependência dessas, ou, ainda, no seu local de trabalho, desde que seja ele o titular ou responsável pelo estabelecimento ou empresa” (BRASIL, 2003).

A validade do Certificado de Registro de Armas de Fogo condiciona-se a verificação periódica de uma série de requisitos. Uns estão estabelecidos na Lei n. 10.826/03 e outros no Decreto n. 5.123/04.

$\mathrm{O}$ art. $5^{\circ}, \$ 2^{\circ}$, da Lei n. 10.826/03 dispóe que Certificado de Registro de Arma de Fogo tem validade de 03 anos. Isso porque "os requisitos de que tratam os incs. I, II e III do art. $4^{\circ}$ deverão ser comprovados periodicamente, em período não inferior a 3 (três) anos, na conformidade do estabelecido no regulamento desta lei, para renovaçáo do Certificado de Registro de Arma de Fogo" (BRASIL, 2003). 
O art. $4^{\circ}$ e incisos da Lei n. 10.826/03, por sua vez, assim dispóe:

Para adquirir arma de fogo de uso permitido o interessado deverá, além de declarar a efetiva necessidade, atender aos seguintes requisitos: I - comprovação de idoneidade, com a apresentação de certidôes negativas de antecedentes criminais fornecidas pela Justiça Federal, Estadual, Militar e Eleitoral e de não estar respondendo a inquérito policial ou a processo criminal, que poderão ser fornecidas por meios eletrônicos; (Redação dada pela Lei n. 11.706, de 2008); II - apresentação de documento comprobatório de ocupação lícita e de residência certa; III - comprovação de capacidade técnica e de aptidáo psicológica para o manuseio de arma de fogo, atestadas na forma disposta no regulamento desta Lei (BRASIL, 2003).

O Decreto n. 5.123/04, que regulamenta a Lei n. 10.826/03, estabelece as condiçóes do segundo prazo de caducidade. O art. $16, \$ 2^{\circ}$, do Decreto n. 5.123/04 estabelecia que o proprietário da arma deverá, a cada três anos, comprovar os requisitos constantes do art. 12, incs. IV, V, VI e VII sob pena de levar a caducidade do Certificado de Registro de Arma de Fogo. Os requisitos originais eram os seguintes:

IV - comprovar no pedido de aquisição e em cada renovação do registro, idoneidade e inexistência de inquérito policial ou processo criminal, por meio de certidôes de antecedentes criminais fornecidas pela Justiça Federal, Estadual, Militar e Eleitoral;

$\mathrm{V}$ - apresentar documento comprobatório de ocupaçáo lícita e de residência certa;

VI - comprovar, em seu pedido de aquisição e em cada renovação de registro, a capacidade técnica para o manuseio de arma de fogo atestada por empresa de instruçáo de tiro registrada no Comando do Exército por instrutor de armamento e tiro das Forças Armadas, das Forças Auxiliares ou do quadro da Polícia Federal, ou por esta habilitado; e

VII - comprovar aptidão psicológica para o manuseio de arma de fogo, atestada em laudo conclusivo fornecido por psicólogo do quadro da Polícia Federal ou por esta credenciado" (BRASIL, 2004). 
O Decreto n. 6.715/2008 dá nova redação aos incs. IV e VI do art. 12 do Decreto n. 5.123/2003 que passam a ter a seguintes redaçôes:

IV - comprovar, em seu pedido de aquisição e em cada renovação do Certificado de Registro de Arma de Fogo, idoneidade e inexistência de inquérito policial ou processo criminal, por meio de certidōes de antecedentes criminais da Justiça Federal, Estadual, Militar e Eleitoral, que poderâo ser fornecidas por meio eletrônico;

VI - comprovar, em seu pedido de aquisição e em cada renovação do Certificado de Registro de Arma de Fogo, a capacidade técnica para o manuseio de arma de fogo; [...] (BRASIL, 2008).

Por fim, o Decreto n. 8.935/16 dá nova redação aos incs. IV e VI do art. 12 do Decreto n. 5.123/03 que passam a ter a seguinte redação:

IV - comprovar, em seu pedido de aquisição do Certificado de Registro de Arma de Fogo e periodicamente, a idoneidade e a inexistência de inquérito policial ou processo criminal, por meio de certidōes de antecedentes criminais da Justiça Federal, Estadual, Militar e Eleitoral, que poderão ser fornecidas por meio eletrônico;

VI - comprovar, em seu pedido de aquisição do Certificado de Registro de Arma de Fogo e periodicamente, a capacidade técnica para o manuseio de arma de fogo; [...] (BRASIL, 2016).

O mesmo Decreto n. 8.935/16 também deu nova redação ao art. 16 , $\$ 2^{\circ}$, do Decreto n. $5.123 / 03$, que passou a ser assim redigido: " $\$ 2^{\circ}$ Os requisitos de que tratam os incs. IV, V e VII do art. 12 deverão ser comprovados, periodicamente, a cada cinco anos, junto à Polícia Federal, para fins de renovação do Certificado de Registro" (BRASIL, 2016).

Restringiram-se os requisitos a serem demonstrados para renovação do Certificado de Registro de Arma de Fogo. Suprimiu-se a necessidade de comprovar "a capacidade técnica para o manuseio de arma de fogo". O prazo para a verificação periódica dos requisitos foi estendido para cinco anos.

O Decreto n. 9.685/2019 dá nova redação ao art. $16, \$ 2^{\circ}$, do Decreto n. 5.123/03: " $\$ 2$ o Os requisitos de que tratam os incs. IV, V, VI e VII do caput do art. 12 deverão ser comprovados, periodicamente, a cada dez anos, junto à Polícia Federal, para fins de renovação do Certificado de Registro" (BRASIL, 2019). 
O requisito, constante do inc. VI do art. 12 do Decreto n. 5123/03, foi reintroduzido. Em contrapartida, o prazo da comprovaçáo periódica dos requisitos constantes do art. 12, incs. IV, V, VI e VII foi estendido para 10 anos.

A questấo é saber: a nova redaçáo dada pelo Decreto n. 9.685/2019 ao art. 16 , $\$ 2^{\circ}$, do Decreto n. $5.123 / 2003$ tem o efeito de socorrer aquele que possuía, em sua residência, uma arma de fogo de uso permitido sem observância do prazo de renovação de 05 anos, mas dentro do novo limite de 10 anos?

Para desenvolver o presente artigo, será utilizado o método hipotético dedutivo.

\section{Da identificação do elemento em branco}

O tipo penal em análise é assim descrito:

Possuir ou manter sob sua guarda arma de fogo, acessório ou munição, de uso permitido, em desacordo com determinaçáo legal ou regulamentar, no interior de sua residência ou dependência desta, ou, ainda no seu local de trabalho, desde que seja o titular ou o responsável legal do estabelecimento ou empresa (BRASIL, 2003).

Trata-se de uma lei penal em branco.

Preferimos a designação lei penal em branco em vez de norma penal em branco. Nossa posição justifica-se pela relação existente entre lei e norma penal. A lei compóe-se de um preceito e uma sanção. A norma penal é o comando obtido a contrário senso da lei penal. A norma nunca está em branco porque verificada a partir da lei penal em branco já integrada pela norma de complementaçáo. Tipo penal em branco também não é uma terminologia adequada. Horta foi o primeiro, na doutrina brasileira, a alertar para a incorreção da designação tipo penal em branco (HORTA, 2012) 2 .

A lei penal em branco é uma técnica de integração normativa. Para observar o princípio da determinação taxativa ${ }^{3}$, deve integrar a sua estrutura uma norma de complementação. A partir da natureza desta, aquela pode ser classificada como homogênea ${ }^{4}$ ou heterogênea ${ }^{5}$.

2 "Não obstante, discorda-se da expressão empregada por Puppe - elementos em branco dos tipos penais -, por não se reconhecer no tipo, mas apenas na lei penal, a condição variável ou incógnita das obrigaçôes ou proibiçôes cuja infração se puna. O tipo, como figura conceitual ou elemento sistemático da teoria do delito, não admite o vazio. Ao contrário da lei, que é forma ou meio de expressão, o tipo - assim como a norma cuja infração se descreve é conteúdo, é mensagem" (HORTA, 2012, p. 95).

3 O princípio da determinaçáo taxativa é, ao lado do princípio da reserva legal e anterioridade, um dos corolários do princípio da legalidade (LUISI, 2003, p. 17-18). Preferimos a designação determinaçăo taxativa ao invés de taxatividade.

4 "A lei penal em branco homogênea tem como norma de complementaçăo uma lei de mesmo status que a lei penal" (MENDONÇA, 2016, p. 32).

5 As leis penais em branco heterogêneas săo leis penais cujo complemento săo normas de natureza e fonte distintas das leis penais. Sấo normas administrativas federais, estaduais ou municipais, leis estaduais e municipais (MENDONÇA, 2016, p. 35). 
A conduta proibida, descrita no art. 12 da Lei n. 10.826/03, possui um elemento em branco consistente na expressáo "em desacordo com a determinação legal ou regulamentar". Possuir ou manter sob sua guarda arma de fogo só será uma conduta típica se em desacordo com disposição legal ou regulamentar. Sabemos que as normas que complementam o elemento em branco é a própria Lei n. 10.826/03 e o Decreto n. 5123/04. Concluiríamos que a lei penal em branco seria homogênea, na medida em que complementada pela própria Lei n. 10.826/2003, e heterogênea, na medida em que complementada pelo Decreto n. 5.123/03. Todavia, sustentamos que a lei penal em branco é exclusivamente heterogênea. ${ }^{6}$ Possuímos um conceito mais restrito de lei penal em branco homogênea que excluiria as homovitelíneas. $^{7}$

O elemento em branco é o campo vago onde a norma de complementação se integra. É importante diferenciá-lo do elemento normativo. Horta afirma que:

[...] o que distingue os elementos em branco das leis penais, dos elementos normativos do tipo é a referência que aqueles fazem ao conteúdo imperativo de uma norma extrapenal, legal ou regulamentar, estabelecida por ato diverso da própria lei penal, sem remissão à qual nấo se extrai da lei um comando dotado de sentido (HORTA, 2012, p. 253).

Para Gatta (2008), as leis penais que possuem, em sua estrutura, elementos normativos jurídicos são completas. Por isso, sua integração normativa é aparente. Ao contrário da lei penal em branco que, incompleta, se vale de uma integração normativa real. ${ }^{8} \mathrm{~A}$ integração real e aparente seria a base de distinção, em Gatta

6 A lei penal em branco homogênea ou homóloga, por seu turno, por (sic) ser homovitelínea ou heterovitelínea: é homovitelínea quando o complemento normativo emana da mesma instância legislativa e se encontra na mesma estrutura normativa da descrição típica. O tipo incriminador e o complemento fazem parte da mesma estrutura normativa." [...]. É heterovitelínea quando o complemento normativo emana da mesma instância legislativa mas não se encontra na mesma estrutura normativa da descrição típica” (GARCIA-PABLOS DE MOLINA; GOMES, 2007. p. 72). Ainda sobre a classificaçấo das leis penais em branco homogêneas, Alflen da Silva assevera: "1 - As leis penais em branco em sentido amplo, que fazem uma remissáo interna (homovitelinas), remetem a outros dispositivos contidos na mesma lei. [...]. 2 - Leis penais em branco em sentido amplo que fazem uma remissão externa (heterovitelinas) sấo aquelas que remetem a outra lei formal, porém emanadas da mesma instância legislativa” (ALFLEN DA SILVA, 2004. p. 68-69).

7 "Não há, nas leis penais em branco homogêneas homovitelíneas, o mesmo objetivo de promover a integração do ordenamento jurídico, observado nas heterovitelíneas. A norma penal não pode estar em branco, mas somente a lei. A norma é obtida a contrário senso da lei, mas nada restringe a norma a um artigo de um documento legal. Esses sáo pontos que nos levam a dúvidas de que as interpretaçôes autênticas contextuais sejam hipóteses de leis penais em branco. Segundo Oliver Calderon, a maioria da doutrina espanhola também nảo inclui as leis penais em branco homogêneas homovitelíneas entre o conceito de lei penal em branco. Trata-se de uma posição intermediária entre os conceitos de lei penal em branco de Binding e Mezger" (MENDONÇA, 2016, p. 34-35).

8 "Quella distinzione mostra come solo alcune delle norme in vario modo richiamate della legge penale possono dirsi vere e proprie norme integratrici: quelle che contribuiscono a descrivere la fattispecie legale astratta e, quindi, a delineare il giudizio di disvalore espresso dal legislatore nella configurazione de una determinata figura del reato (43). Si tratta, come sappiamo, delle norme chiamate a 'riempire' il precetto di norme penali in tutto o in parte 'in bianco', e delle norme definitore. Altre norme, invece, sono apparentemente integratrici: pur essendo richiamate dalla legge penale, non contribuiscono né a descrivere la fattispecie legale astratta, né a delineare il giudizio di disvalore espresso dal legislatore nella configurazione di una certa figura di reato. Si tratta - sappiamo anche questo - delle norme cui si riferiscono gli elementi normativi della fattispecie, giuridici o extragiuridici, quali criterio o presupposti delle qualifi- 
(2008), nos elementos em branco dos normativos jurídicos. Discordamos parcialmente. A argumentação de Gatta (2008) não nos parece ser aplicável às leis penais de remissão interpretativa. ${ }^{9}$ Não convém seguir nessa discussão, porque não é o caso do art. 12 da Lei n. 10.826/03.

A expressão "em desacordo com a regulamentação legal ou regulamentar" é um elemento em branco complementado pelo Decreto n. 5.123/04. A posse ou manutençáo de uma arma de fogo em desacordo com qualquer disposiçáo regulamentar torna a conduta típica. Todas as regulamentaçóes atuais acerca da posse ou manutençấo de arma de fogo integram a lei penal. Interessa-nos, como ficou claro na introdução, o disposto no art. $16, \$ 2^{\circ}$, do Decreto n. 5.123/04 com a redação dada pelo Decreto n. 9.685/19.

\section{Do estado da arte: doutrina e jurisprudência}

Entre nós, há dois livros que possuem capítulos específicos sobre o tema, tratado no presente artigo: um de Tarcísio Mendonça (2016) e outro de autoria Fábio Guaragni e Marion Bach (2014). José Henrique Pierangeli (2006) tem um artigo publicado no livro Escritos jurídicos-penais. Na Itália, o trabalho de Gian Luigi Gatta (2008) é digno de nota.

A questáo da sucessão de norma de complementaçáo do tempo chegou ao Supremo Tribunal Federal por conta de nossos sucessivos planos econômicos, vivenciados no último século. A matéria era, normalmente, tratada no contexto no art. $2^{\circ}$, inc. VI, da Lei n. 1.521/51. A Suprema Corte negava a abolitio criminis a partir da sucessão de norma de complementação no tempo. As discussóes do presente tema, no contexto do art. $2^{\circ}$, inc. VI, da Lei n. $1.521 / 51$, náo tem muita valia. $\mathrm{O}$ mencionado dispositivo legal descreve uma lei penal em branco. Ocorre que a lei é também excepcional. E todos sabemos da disciplina que o código penal reserva às leis penais temporárias e excepcionais. ${ }^{10}$

che da essi espresse" (GATTA, 2008, p. 247). Nossa tradução: "Essa distinçâo mostra que apenas algumas das regras de várias formas mencionadas na lei penal podem ser consideradas verdadeiras e adequadas normas de integração: aquelas que contribuem para descrever o caso jurídico abstrato e, portanto, delinear o julgamento de valor negativo expresso pelo legislador na configuraçăo de um específico figura do crime (43). Como sabemos, trata-se das normas chamadas a "preencher" o preceito das normas penais no todo ou em parte "em branco", e das normas definidoras. Outras normas, por outro lado, são aparentemente complementares: embora sejam referidas pelo direito penal, não contribuem para descrever o caso jurídico abstrato, nem para delinear o julgamento do valor negativo expresso pelo legislador na configuração de um determinado tipo penal".

9 As leis penais em branco que evidenciam, por sua estrutura, a demanda por uma norma de complementaçáo são as de remissão geral, as de remissão específica que delegam à norma de complementação a restriçáo ou definição da ilicitude. Nessas hipóteses, a partir da diferença apontada por Gatta entre elemento em branco e normativo jurídico, fica claro que estamos diante de leis penais em branco. Gatta é insuficiente para explicar a diferença entre elemento em branco e normativo jurídico quando a lei penal em branco faz uso de uma remissão interpretativa (MENDONÇA, 2016, p. 83).

10 "O Ministro Nelson Hungria, em seu voto, argumentou que a mudança ou alteraçáo dos atos normativos que complementam a lei penal em branco năo pode levar à aplicaçăo do princípio da retroatividade in melius. Pouco importa a alteraçáo ou mesmo a extinçăo do ato administrativo que complementa a lei penal em branco, porque 
O Supremo Tribunal Federal começou a admitir, em tese, a aplicação da retroatividade de norma de complementação de lei penal em branco menos gravosa no julgamento do HC 73.168/SP. Nota-se que a admissão da possibilidade se deu tem tese, haja vista que, no caso concreto, a abolitio criminis não foi aplicada. ${ }^{11}$

No HC 94.397/BA, o Supremo Tribunal Federal reconheceu a abolitio criminis a partir da sucessão de norma de complementação no tempo. Não realizou, todavia, qualquer reflexão mais profunda sobre os limites na sucessão, no tempo, de norma de complementação de lei penal em branco (BRASIL, 2010a).

No Superior Tribunal de Justiça, dois casos se destacam: HC 113.094/BA (BRASIL, 2009) e HC 150.032/MG (BRASIL, 2010b). Os dois Habeas Corpus trataram do crime descrito no art. $1^{\circ}$, inc. I, da Lei n. 8.176/91. Os pacientes foram acusados de vender combustível em desacordo a regulamentação da ANP ${ }^{12}$. Ao arrepio da Resolução n. 248/2000, não guardaram amostras testemunhas dos dois últimos carregamentos. Ocorre que a Resolução n. 248/2000 foi revogada pela Resolução n. 09/2007. Manter amostras testemunhas dos dois últimos carregamentos passou a ser uma faculdade. O responsável pelo posto de gasolina poderia optar por manter, em seu poder, um Boletim de Conformidade expedido pelo distribuidor.

Esses Habeas Corpus são importantes porque permitiram ao Superior Tribunal de Justiça debater o tema, objeto do presente artigo, com um pouco mais de profundidade. O HC 113.094/BA foi o primeiro das duas açôes constitucionais que colocamos em relevo. Foi reconhecida, por maioria de votos, a abolitio criminis. $\mathrm{O}$ voto majoritário entendeu que o princípio da anterioridade se aplica de forma plena à sucessão de norma de complementaçáo de lei penal em branco. O voto divergente, da lavra da Ministra Maria Thereza, deixou de reconhecer a abolitio criminis. Entendeu que o princípio da anterioridade só se aplica quando a norma de complementação posterior excluir o conteúdo do injusto. E isso não aconteceu no caso em análise. A Resolução n. 09/2007 não eliminou a necessidade de controle do combustível posto à venda. Só o previu de forma distinta.

O HC 150.032/MG não teve voto divergente. Acompanhou a orientaçáo majoritária encampada pelo Superior Tribunal de Justiça no HC 113.094/BA. Perdeu uma ótima oportunidade de aprofundar as discussóes levantadas pelo voto divergente, subscrito pela Ministra Maria Thereza.

o crime sempre deve estar ligado às condiçóes do mercado à época de sua ocorrência. Além do mais, a julgar pela demora do processo penal e o tempo curto em que vigiam os tabelamentos de preços, os autores de crimes contra a economia popular terminariam impunes" (MENDONÇA, 2016, p. 115).

11 "A norma que complementa o preceito penal em branco, importa real modificação da figura abstrata nele prevista ou se assenta em motivo permanente, insusceptível de modificar-se por circunstâncias temporárias ou excepcionais, como sucede quando do elenco de doenças contagiosas se retira uma por se haver demonstrado que não tem ela tal característica" (BRASIL, 1995).

12 Agência Nacional de Petróleo. 
Há três correntes que buscam explicar o problema da sucessão, no tempo, de norma de complementação de lei penal em branco: teoria clássica, aplicação plena do princípio da anterioridade e teorias intermediárias.

\section{Correntes doutrinárias}

\subsection{Teoria clássica}

A teoria clássica sustenta a inaplicabilidade plena do princípio da anterioridade na sucessão da norma de complementação de lei penal em branco no tempo. Baseia-se na ideia de que a norma de complementação não integra a lei penal em branco. A primeira é somente um pressuposto de aplicabilidade da segunda. Dessa forma, a norma de complementação estaria fora do âmbito de incidência do princípio da anterioridade da lei penal. As primeiras referências a esse posicionamento ocorreram na Corte di Cassazione Italiana e no Reichsgericht alemão ${ }^{13}$.

Alarcon Borges (2015) atribui três fundamentos à teoria clássica: formalista, material e jurisprudencial.

A formalista lastreia-se na distinçâo entre lei e norma. A norma de complementação não integra a lei penal, somente a norma. Como o princípio da anterioridade só incide sobre a lei, não se aplicaria ao conflito de norma de complementaçáo de lei penal em branco no tempo. ${ }^{14}$

O fundamento material justifica a não aplicaçáo da abolitio criminis em razão do princípio da obediência às normas jurídicas. Mesmo a norma de complementação posterior sendo mais benéfica ao acusado, não há de se ignorar o fato de que o indivíduo, no tempo da açáo, inobservou uma norma jurídica.

13 "La primera postura, denominada tradicional, se mostraba mayoritariamente contraria a la aplicación retroactiva de las modificaciones favorables al reo producidas en las normas penales en blanco a consecuencias de una variación en la normativa extrapenal objeto de remisión, Su principales exponentes se encontraban en la Corte di Cassazione Italiana y en la jurisprudencia sentada por el Reichsgericht alemán, seguida por los tribunales inferiores e incluso por algún pronunciamiento inicial del Bundesgerichtshof (Tribunal Supremo federal alemán)” (ALARCON BORGES, 2015). Nossa tradução: "A primeira posição, denominada tradicional, era em grande parte contrária à aplicação retroativa das modificaçóes favoráveis aos internos, produzidas nas normas penais em branco, às consequências de uma variaçáo do objeto de referência extra-penal, cujos principais expoentes estavam na Corte di Cassazione Italiana e na jurisprudência estabelecida pelo Reichsgericht alemão, seguida pelos tribunais inferiores e até mesmo por algum pronunciamento inicial do Bundesgerichtshof".

14 "La básicamente formalista, que partiendo de la distinción entre normas y leyes penales, plantea que la expresión leyes, empleada en el artículo 2 del StGB, para aludir a la aplicación retroactiva, debía ser interpretada como alusiva a las 'leyes penales', pero no a las 'normas'; en conclusión, sólo podría aplicarse retroactivamente una modificación de las leyes favorables al reo, pero no una modificación de las 'normas', que como se conocen, según la teoría de Binding, no pertencen al Derecho penal, sino al Derecho Público general. La 'ley' es el total estado jurídico en que descansa la punibilidad, en ella se incluyen las disposiciones que completan a las leyes penales en blanco. Si una modificación de las mismas repercute una atenuación, es de aplicación el articulo 2, ante mencionado" (ALARCON BORGES, 2015). Nossa tradução: "O basicamente formalista, que baseado na distinçấo entre regras e leis criminais, afirma que as leis de expressão, usadas no Artigo 2 do StGB, para se referir a aplicação retroativa, devem ser interpretadas como aludindo às 'leis criminais', mas não às "normas"; Em conclusão, apenas uma modificação das leis favoráveis ao acusado poderia ser aplicada retroativamente, mas não uma modificação das 'normas', que como são conhecidas, de acordo com a teoria de Binding, não pertencem ao direito penal, mas ao direito público geral. A "lei" é o status legal total sobre o qual a punibilidade depende, incluindo as disposiçóes que completam as leis criminais em branco. Se uma modificação do mesmo tiver uma atenuação, aplica-se o Artigo 2, conforme mencionado acima”. 
O fundamento de matriz jurisprudencial, a que se refere Alarcon Borges, sustenta-se na premissa de que o direito penal seria meramente sancionador. $\mathrm{O}$ princípio da anterioridade não alcançaria as normas de complementação que moldam e delimitam os bens jurídicos a serem tutelados pela lei penal ${ }^{15}$.

Se aplicarmos a teoria clássica ao problema, objeto do presente artigo, veremos que o agente não poderá valer-se da abolitio criminis. A nova redação, dada ao art. $16, \$ 2^{\circ}$, do Decreto n. 5.123/03 pelo Decreto n. 9.685/19, náo retroage para ampliar o prazo de validade de Certificados de Registros de Arma de Fogo.

Discordamos da teoria clássica. Se considerarmos a norma de complementação um pressuposto de aplicabilidade da lei penal e náo elemento de sua estrutura, teremos de admitir que a lei penal em branco afronta o princípio da determinaçáo taxativa. ${ }^{16}$

Também não acreditamos ser razoável sustentar a legitimidade da pena criminal na desobediência ao comando estatal. Aquele que mata alguém não é punido porque desobedeceu ao comando "não matar". É apenado porque, ao desobedecer ao comando estatal, lesou o bem jurídico vida.

Concluímos que a teoria clássica não traz a melhor solução. Portanto, terminamos por abandoná-la. Isso não implica reconhecer como correta a aplicação plena do princípio da anterioridade.

\subsection{Teoria da Retroatividade Plena}

Silva Sanchez (1992) sustenta que a aplicação plena do princípio da anterioridade na resoluçáo do conflito de norma de complementação de lei penal em branco no tempo tornou-se uma corrente majoritária após a 2a Guerra Mundial.

Parte-se da premissa de que a norma de complementaçáo integra a lei penal e, portanto, está sob o âmbito de incidência do princípio da anterioridade. Welzel (1956) pensa dessa forma, embora excetue as leis penais em branco que também são temporárias.

Para os adeptos da corrente, ora em análise, a nova redação do art. $16, \$ 2^{\circ}$, do Decreto n. 5123/04, dada pelo Decreto n. 9.685/19 retroage para extinguir a

15 "Por último, la vertiente de índole jurisprudencial, que toma como punto de partida la consideración de que las normas penales no establecen por sí mismas sus "objetos de protección", sino que se limitan a prestar protección penal a bienes jurídicos definidos fuera de las mismas, en otros sectores del ordenamiento jurídico. Sentado esto, se considera que el articulo $2 \mathrm{StGB}$ se refiere solo -a efectos de su eventual aplicación retroactiva-, a modificaciones favorables de las normas protectoras, que son las que merecen realmente el apelativo de "leyes penales"; no, en cambio, a variaciones que afecten a la configuración del bien jurídico" (ALARCON BORGES, 2015).

16 "A integraçấo da norma de complementaçấo à lei penal em branco nos parece clara. Do contrário, admitiríamos leis penais em branco que violariam o princípio da determinaçăo" (MENDONÇA, 2016, p. 95). Pierangeli tem o mesmo posicionamento: "Entendemos que a legislaçáo extrapenal integra o tipo, pois, para nós resulta incompreensível a existência de uma lei penal que náo individualize a conduta que proíbe, e a ela associe uma pena" (PIERANGELI, 2006, p. 128). 
punibilidade daquele que possuía ou mantinha uma arma de fogo com Certificado de Registro de Arma de Fogo vencido há não mais do que 10 anos. A solução, todavia, não nos parece ser tão simples.

Há hipóteses em que a norma de regulamentação, posterior menos gravosa, exclui a ilicitude da conduta praticada. Há outras em que a norma de complementação somente regulamenta o ilícito - que se mantém preservado - de uma forma distinta. Na segunda hipótese, o injusto persiste. A tutela do bem jurídico somente é regulamentada de forma distinta. Na primeira hipótese, há, pela norma de complementação, um completo esvaziamento do injusto. Isso pode ocorrer em razão de uma revaloração da conduta outrora típica. Ou porque o legislador passa a compreender que o bem jurídico náo é mais digno de tutela penal ou porque entende que a conduta, outrora típica, não é grave o suficiente a ponto de merecer uma resposta penal. É possível também que, em razão de uma alteração do quadro fático, perceba-se que a conduta, outrora típica, não viola o bem jurídico de forma a merecer uma resposta penal.

Imaginemos que uma portaria " $\mathrm{x}$ " do IBAMA proíba a pesca no rio das Velhas em um determinado trecho em Matozinhos. Os técnicos perceberam que, naquela região, houve um desequilíbrio no ecossistema que ameaçava os peixes. Era necessário que a pesca cessasse. Aquele que desobedecesse a proibição, cometeria o crime descrito no art. 34 da lei 9.605/98. Tempo depois, em razáo de uma conjunção de fatores, ficou constatado que os peixes da região não estavam mais em perigo. O IBAMA revoga a portaria "x". É razoável admitir que o autor da pesca proibida a seu tempo possa valer-se da abolitio criminis? Imaginemos que não estamos tratando de uma lei penal excepcional. Os dados fáticos que interferiam no ecossistema e fragilizavam os peixes eram relativamente estáveis. A incidência do princípio da anterioridade no conflito de norma de complementação no tempo não nos parece oferecer, para o nosso caso hipotético, uma solução adequada. E a resposta para esse desconforto parece estar em seus fundamentos.

\subsubsection{Princípio da anterioridade: fundamentos}

O princípio da anterioridade impede que uma lei penal seja aplicada a fatos anteriores a sua vigência. Implica dizer que a lei penal náo retroage para alcançar fatos passados. Não desconhecemos os fundamentos políticos do princípio da anterioridade e da própria legalidade. Também não ignoramos a importância do postulado da legalidade para a restriçáo e racionalidade do poder punitivo estatal. Ocorre que, quando aplicamos o princípio da anterioridade ao conflito de norma de complementaçáo de lei penal em branco no tempo, o resultado 
não é satisfatório. Reputamos tal fato à função regulamentadora que a norma de complementação exerce em relação ao disposto na lei penal. Acreditamos que a aplicação do princípio da anterioridade possa ser mitigada, restringindo a incidência da abolitio criminis, observando o fenômeno, objeto do presente estudo, pelas vias do princípio da isonomia. Registra-se que essas consideraçóes são restritas ao conflito de norma de complementação de lei penal em branco no tempo.

O princípio da isonomia não implica tratar todos da mesma forma. Consiste em tratar o igual de forma igual e o desigual de forma desigual. Havendo uma base fática, é possível tratar indivíduos de forma distinta, no sentido de, superando as desigualdades fáticas, equilibrarmos os "pratos da balança”. A publicação de uma lei penal é um fato que permite tratar dois indivíduos que praticaram a mesma conduta de forma distinta. $\mathrm{O}$ indivíduo " $\mathrm{A}$ " praticou a conduta ' $\mathrm{Y}$ '. No dia seguinte entra em vigor lei penal que tipifica a conduta " $Y$ ", prometendo a seu autor uma pena de reclusão de 01 a 05 anos. Dois dias após a publicação da lei, o indivíduo " $\mathrm{B}$ " pratica a mesma conduta " $Y$ " e é condenado a 01 ano de prisão. O fato de a lei penal já ter sido publicada permitiu ao indivíduo "B" orientar seu agir. Ainda assim, optou por cometer a conduta típica. O indivíduo "A" não teve a mesma possibilidade. $\mathrm{O}$ discrimen que permite o tratamento diverso a dois indivíduos que praticaram a mesma conduta está evidenciado.

Interessa-nos em especial a outra face do princípio da anterioridade. A lei penal que tipificava a conduta "Y" foi revogada. A conduta, outrora típica, torna-se atípica. Todos sabemos que a consequência é a extinção da punibilidade pela abolitio criminis. Vamos analisar a questão pela via do princípio da isonomia.

$\mathrm{O}$ indivíduo "A" pratica a conduta típica " $\mathrm{Y}$ ". Dois dias após, a lei penal que tratava a conduta como criminosa é revogada. O indivíduo "B", dois dias após a revogação, pratica a conduta "Y", outrora típica. Caso não houvesse a abolitio criminis, dois indivíduos iguais em seus atos seriam tratados de forma distinta, violando com isso o princípio da isonomia.

Imagine que a pesca de lambari esteja proibida no rio Paraopeba. Os estudos indicam que a população de lambari, naquele rio, reduziu-se sensivelmente. Os órgãos ambientais responsáveis trabalham no sentido de repovoar o rio. A população de lambaris atinge um nível bem satisfatório. A portaria do IBAMA que proibia a pesca de lambaris é revogada. Aquele que pescou lambaris, quando da vigência da proibição, pode, pela revogação da mencionada portaria, valer-se da abolitio criminis?

Se pensarmos somente no princípio da anterioridade, aplica-se a abolitio criminis. Todavia, se observarmos a questão sob a ótica do princípio da isonomia, 
as certezas acerca da extinção da punibilidade ficam rarefeitas. Aquele que pescou lambari quando era proibido fazê-lo é distinto daquela que o fez quando era permitido. Não porque um inobservou a norma jurídica e o outro não, mas porque o primeiro, ao praticar a conduta, lesou o bem jurídico. $\mathrm{O}$ segundo não. A modificação do quadro fático faz com que o primeiro seja, em seus atos, diferente do segundo, justificando, portanto, o tratamento desigual.

Cientes de que a teoria da retroatividade plena não apresenta soluçóes satisfatórias, passamos ao estudo das teorias intermediárias.

\subsection{Teorias intermediárias}

As teorias intermediárias partem da premissa de que a clássica e da retroatividade plena não apresentam soluçôes satisfatórias para o conflito de normas de complementação de lei penal em branco no tempo. Embora a norma de complementação integre a estrutura da lei penal, a aplicação plena do princípio da anterioridade não nos parece correto. Reputamos tal fato a função regulamentadora que a norma de complementação exerce sobre a lei penal em branco. Resta-nos seguir a trilha das teorias intermediárias.

\subsubsection{Alteração dos dados fáticos}

A aplicação da abolitio criminis é condicionada a uma modificação da norma de complementação lastreada na alteração de dados fáticos, capazes de alterar a valoração que se faz de uma determinada conduta, outrora proibida. ${ }^{17}$

A análise desta corrente nos impóe tratar das leis penais temporárias ou excepcionais. A lei penal temporária já nasce com data marcada em seu próprio texto para que cesse a sua vigência. A lei penal excepcional tem sua vigência condicionada a uma situaçáo de excepcionalidade. Ocorre que nem toda lei penal temporária ou excepcional é uma lei penal em branco. Nem toda lei penal em branco é temporária e excepcional.

É bem verdade que há uma coincidência de fundamentos. Tanto a lei penal temporária ou excepcional quanto a lei penal em branco podem atender a uma

17 "Según el referido criterio, adoptado por algún autor, el principio de retroactividad de las disposiciones posteriores más favorables al reo, no sería aplicable retroactivamente cuando su introducción hubiera sido debida a la apreciación de un cambio de circunstancias, esto es, a un elemento fáctico. En cambio, dicha nueva lex mitior gozaría de aplicación retroactiva cuando la introducción de la modificación favorable al reo tuviera su origen en un cambio en la valoración jurídica, esto es, es un factor axiológico" (SILVA SANCHEZ, 1992, p. 441). Nossa Tradução: "De acordo com o critério mencionado, adotado por alguns autores, o princípio da retroatividade de disposiçóes posteriores mais favoráveis ao ofensor, nâo se aplicaria retroativamente quando sua introduçấo fosse devida à apreciação de uma mudança de circunstâncias, isto é, a um elemento de fato. Por outro lado, esse novo lex mitior teria aplicação retroativa quando a introdução da modificaçăo favorável ao ofensor tivesse sua origem em uma mudança na avaliaçấo legal, ou seja, é um fator axiológico". 
situação transitória. Ocorre que esse não é o único fundamento de política criminal que inspira o legislador a utilizar a técnica da lei penal em branco. Ela também se justifica para atender a juízos de valor que prescindem de um conhecimento técnico específico. Ou pode servir para que cada Estado ou município possam contribuir, por meio de normas de complementação, na construção de leis penais.

Nos termos dessa corrente, a sucessáo de norma de complementação no tempo levaria a abolitio criminis se não motivada por uma alteração fática que levasse o legislador a valorar a conduta de forma distinta.

Imaginemos que, após o desastre em Brumadinho, seja necessário proibir, por meio de portaria do órgão ambiental competente, a pesca no rio Paraopeba. Imaginemos que um indivíduo "X", inobservando a determinação, pratique o crime descrito no art. 34 da Lei n. 9.605/98. Por hipótese, imaginemos que a situação se normalize e o rio Paraopeba se veja livre de toda a poluição. A portaria é revogada. Pode o indivíduo " $\mathrm{x}$ " valer-se da abolitio criminis?

Entendemos que, dentro da perspectiva da corrente ora em análise, não. Isso porque houve uma alteração do quadro fático que levou o legislador a valorar a conduta de forma distinta. Na primeira oportunidade, lesava ou expunha a risco o bem jurídico penalmente tutelado. Na segunda não. É esse o discrimen que permite tratar de forma diversa o indivíduo " $\mathrm{x}$ " e $\mathrm{o}$ indivíduo " $\mathrm{y}$ ".

Explicitadas as bases dessa corrente, vamos aplicá-la ao caso, objeto do presente artigo. Aquele que mantinha uma arma em sua residência com certificado de registro de arma de fogo vencido quando da entrada em vigor do Decreto n. 9.685/19 poderia valer-se da abolitio criminis se o certificado não foi emitido há mais de 10 anos. Isso porque não há nenhuma alteração de dados fáticos que justifique um revaloração da conduta típica. A nova norma de complementação só entendeu por bem disciplinar o controle de arma de fogo de forma menos rigorosa.

\subsubsection{Alteraçấo do núcleo do ilícito típico}

Essa corrente nasceu no Bundesgerichtshofe não tinha como objeto inicial tratar da sucessão de normas de complementação de lei penal em branco no tempo. O Bundesgerichtshof cuidou de uma hipótese de sucessão de leis penais no tempo. A lei posterior incluiu uma qualificadora e retirou outra do crime de roubo. $\mathrm{O}$ acusado incidiu nas duas qualificadoras: a que não sobreviveu à modificação da lei penal e aquela que foi introduzida por ela. $\mathrm{O}$ sujeito ativo foi condenado por roubo qualificado porque o Tribunal alemão compreendeu que a nova lei não modificou o núcleo da conduta proibida. ${ }^{18}$

18 "O critério da continuidade do ilícito típico não nasceu para tratar da sucessão de uma norma de complementação. Seu berço foi o Bundesgerichtshof. Foi primeiro concebido pela jurisprudência e depois duramente criticado pela 
Essa corrente, aplicada ao texto da lei penal propriamente dita, nos parece uma clara negação ao princípio da anterioridade. Isso porque mitiga o princípio da legalidade para prestar homenagens a uma necessidade político criminal de imposiçáo de pena. Nenhum direito, minimamente liberal e democrático, pode da luz a uma perspectiva tão sombria. ${ }^{19}$

Essa corrente não causa tanta estranheza quando aplicada à sucessão de normas de complementação no tempo por conta da natureza regulamentadora desta em relação às leis penais.

Os italianos tratam da corrente, ora em análise, denominando-a de continuidade do ilícito típico. ${ }^{20} \mathrm{~A}$ nova norma de complementação só poderá gerar a extinção da punibilidade pela abolitio criminis quando alterar o objeto de tutela penal. Em outras palavras, se a norma de regulamentaçáo continuar a tutelar o bem jurídico penalmente tutelado, de uma forma mais branda, não haverá abolitio criminis.

Se adotarmos essa corrente, daremos outra resposta ao problema, ora em análise. Aquele que manteve uma arma de fogo em sua residência com certificado de registro de arma de fogo vencido há um ano, quando da vigência do Decreto $\mathrm{n}$. $9.865 / 19$ não poderá valer-se da abolitio criminis. Isso porque a nova redação dada ao art. $16, \$ 2^{\circ}$, do Decreto n. 5.123/04 e agora dada pelo Decreto n. 9.865/19 não alterou a tutela do bem jurídico, mas a disciplinou de forma distinta.

\subsubsection{Posiçáo da doutrina}

Jakobs filia-se à corrente diferenciadora. Seu critério de diferenciação passa por estabelecer categorias de leis penais em branco. No primeiro caso, a lei penal serve para assegurar a observância da norma de complementaçáo. No segundo, a lei garante o efeito de regulamentação da norma de complementação. A sucessão de normas de complementaçáo, no segundo grupo de leis penais em branco, não leva à abolitio criminis. $\mathrm{O}$ mesmo não pode ser dito em relação ao primeiro doutrina. O berço da teoria da continuidade do tipo de ilícito não oferece boas perspectivas. O Bundesgerichtshof tratou do delito de "roubo grave". Houve uma sucessáo de leis penais no tempo. Lei posterior retira uma qualificadora e insere duas outras até então inexistentes. Um agente comete o crime de roubo grave nos termos da lei penal de seu tempo. Por coincidência, incide também nas hipóteses futuras de qualificadoras do roubo. Questiona-se: o agente pode responder por roubo grave? O tribunal alemão entendeu pela punição do autor pelo crime de "rapina grave". Justificou-se, no entender de Gatta, sustentando que a sucessâo de leis penais no tempo não determinou uma alteraçăo do objeto da tutela penal, preservando o núcleo do ilícito” (MENDONÇA, 2016, p. 105).

19 "O raciocínio desenvolvido, primeiramente pela jurisprudência alemã, é um subterfúgio teórico que tem como objetivo negar a aplicação do princípio da retroatividade fundando-se, em última medida, na necessidade político-criminal da pena (prevenção geral e especial). Mesmo que a conduta não mais se adeque à nova lei penal, havendo uma identidade de bens jurídicos penalmente tutelados, a puniçáo permanece. Se a nova lei continua a dar relevância jurídica ao mesmo bem jurídico tutelado pela lei anterior é porque a necessidade da pena se mantém" (MENDONÇA, 2016, p. 106).

20 "Os italianos denominam esse critério de "continuidade do tipo de ilícito". Não haverá abolitio criminis se a lei posterior não alterar o núcleo do tipo de ilícito. Em outras palavras: havendo uma unidade de bem jurídico entre a lei posterior e a anterior não se verifica a abolitio criminis, mesmo que formalmente o fato anterior não encontre um juízo positivo de subsunção típica em relação à lei penal posterior" (MENDONÇA, 2016, p. 104). 
grupo $^{21}$. Parece-nos que Jakobs se filia à teoria da continuidade do injusto, com a particularidade de não fundar o direito penal na tutela de bens jurídicos, mas na vigência da norma.

Marinucci e Dolcini (2012) abraçam a teoria da retroatividade plena. Diferenciam, como nós, elemento em branco do normativo jurídico. Afirmam que a norma de complementação leva à abolitio criminis se estamos cuidando de um elemento em branco. Não o fará se complementar um elemento normativo jurídico. Ora, então toda sucessão de norma de complementação de lei penal em branco gera a extinção da punibilidade pela abolitio criminis. Tratamos da teoria da retroatividade plena.

Gatta (2008) caminha no mesmo sentido de Marinucci e Dolcini. Ele condiciona a abolitio criminis a sucessão, no tempo, de normas de complementação em que se verifica uma integração real que se restringe aos elementos em branco. A integração aparente verifica-se nos elementos normativos jurídicos. Logo, condicionar a abolitio criminis à verificação de uma integração real é circunscrevê-la às leis penais em branco. Gatta, assim como Marinucci e Dolcini, filiam-se à teoria da retroatividade plena.

\section{Consideraçóes finais}

Parece-nos que as teorias clássica e da retroatividade plena não atendem. A primeira parte da premissa é a de que a norma de complementação não integra a lei penal em branco. Isso é um problema porque implica admitir que as leis penais em branco afrontam o princípio da determinação taxativa. A teoria da retroatividade plena também não traz respostas satisfatórias. As teorias intermediárias nos parecem mais adequadas para a resolução do conflito de norma de complementação no tempo. Elas restringem a incidência da abolitio criminis. A questão é que não há um consenso sobre os critérios de restrição da incidência da abolitio criminis. Duas correntes tentam trazer soluçóes ao problema: alteração dos dados fáticos e continuidade do ilícito. Os autores pesquisados não fugiram da dualidade das correntes mencionadas na frase anterior.

Frente à impossibilidade de obter respostas satisfatórias ao problema, objeto do presente artigo, por meio da simples aplicação do princípio da anterioridade, optamos por visualizar o problema por meio do princípio da isonomia.

\footnotetext{
21 Jakobs filia-se à corrente das teorias diferenciadoras ao afirmar ser possível, em casos específicos, que a norma de complementaçăo posterior possa justificar a extinçăo da punibilidade pela abolitio criminis. Para estabelecer um critério diferenciador, devemos, na visăo de Jakobs, estabelecer categorias de leis penais em branco. A classificação das leis penais em branco, proposta por Jakobs, parte da função exercida pela lei penal frente à norma de complementaçấo. No primeiro grupo, a lei penal serve para assegurar a obediência à norma de complementação. No segundo grupo, a lei penal assegura o efeito de regulamentação, objetivo da norma de complementaçăo (MENDONÇA, 2016, p. 107-108).
} 
A norma de complementação estabelece, em relação à lei penal, uma relação de regulamentação. Isso impede que o princípio da anterioridade apresente solução satisfatória em todas as hipóteses estudadas. Se não é possível negar a aplicação da abolitio criminis em todos os casos também não é possível admiti-la sempre. A questão é que não há um consenso sobre o âmbito de incidência da abolitio criminis no caso de sucessão de norma de complementação de lei penal em branco no tempo. O princípio da isonomia nos pareceu suprir as deficiências do princípio da anterioridade para solucionar o problema do âmbito de incidência da abolitio criminis. Isso somente nas hipóteses em que a sucessão da norma de complementação náo eliminou por completo o conteúdo do injusto penal. Isso porque quando elimina, não há dúvidas sobre a incidência da abolitio criminis.

Caso a norma de complementação posterior restrinja o âmbito da tipicidade sem se fundar em qualquer alteração do quadro fático, haverá a incidência da abolitio criminis. Do contrário, viola-se o princípio da isonomia. Ao contrário, se a norma de complementação posterior restringe o âmbito da tipicidade fundada em alteraçóes do quadro fático, náo haverá incidência de abolitio criminis. A alteração do quadro fático funciona como discrimen a permitir o tratamento diverso entre aquele que praticou a conduta proibida antes da alteraçáo da norma de complementação e aquele que praticou a mesma conduta depois.

A nova redaçáo dada ao art. $16, \$ 2^{\circ}$, do Decreto n. 5.123/04 pelo Decreto n. 9.685/19 restringe o âmbito de incidência do tipo penal. Não há nenhum dado fatual que justifique a ampliaçáo do prazo de 05 para 10 anos do certificado de registro de arma de fogo. Há somente uma nova visão política sobre a matéria. O direito não dá o mesmo valor ao controle de arma de fogo que dava antes do Decreto n. 9.685/19. Nesse sentido, não há como não reconhecer a incidência da abolitio criminis àquele que possuía ou mantinha arma de fogo sob sua guarda com o certificado de registro de arma de fogo vencido, desde que não superasse o prazo de 10 anos de sua emissão. Tudo nos termos da nova redação dada ao art. 16, $\$ 2^{\circ}$, do Decreto n. 5.123/04 pelo Decreto n. 9.685/19.

\section{Referências}

ALARCON BORGES, R. Y. La sucesión de leyes en los delitos econónicos configurados como normas penales en blanco: propuestas para no transitar por una época de epílogos. In: PIERRE, M. G. (Coord.). Globalización, delincuencia organizada, expansionismo penal y derecho penal económico en el siglo XXI. Guadalajara: Universidad de Guadalajara; La Habana: Centro de Estudios Martianos, 2015. p. 361-398. 
ALFLEN DA SILVA, P. R. Leis penais em branco e o Direito Penal do risco: aspectos críticos e fundamentais. Rio de Janeiro: Lumen Juris, 2004.

BRASIL. Supremo Tribunal Federal. Habeas Corpus n. 73.168/SP. Rel Min. Moreira Alves. DJ 15.03.1996. Brasília, 21 nov. 1995. Disponível em: <http://redir. stf.jus.br/paginadorpub/paginador.jsp?docTP=AC\&docID=74299>. Acesso em: 18 jan. 2019.

BRASIL. Lei n. 10.826, de 22 de dezembro de 2003. Dispóe sobre registro, posse e comercialização de armas de fogo e munição, sobre o Sistema Nacional de Armas - Sinarm, define crimes e dá outras providências. Disponível em: <http://www. planalto.gov.br/ccivil_03/LEIS/2003/L10.826.htm>. Acesso em: 18 fev. 2019.

BRASIL. Decreto n. 5.123, de $1^{\circ}$ de julho de 2004. Regulamenta a Lei n. 10.826, de 22 de dezembro de 2003, que dispóe sobre registro, posse e comercialização de armas de fogo e munição, sobre o Sistema Nacional de Armas - SINARM e define crimes. Disponível em: <http://www.planalto.gov.br/ccivil_03/_Ato20042006/2004/Decreto/D5123.htm>. Acesso em: 18 fev. 2019

BRASIL. Decreto n. 6.715, de 29 de dezembro de 2008. Altera o Decreto n. 5.123, de $1^{\circ}$ de julho de 2004, que regulamenta a Lei n. 10.826, de 22 de dezembro de 2003, que dispóe sobre registro, posse e comercialização de armas de fogo e munição, sobre o Sistema Nacional de Armas - SINARM e define crimes Disponível em: <http://www.planalto.gov.br/ccivil_03/Ato2007-2010/2008/Decreto/D6715.htm\#art1>. Acesso em: 18 fev. 2019.

BRASIL. Superior Tribunal de Justiça. Habeas Corpus n. 113.094/BA. Rel. Desembargadora convocada Jane Silva, DJe 18.05.2009. Brasília, DF, 19 mar. 2009. Disponível em: <https://ww2.stj.jus.br/processo/revista/documento/mediado/?componente $=$ ATC $\&$ sequencial $=4314206 \&$ num_registro $=200801752470 \& \mathrm{da}-$ ta $=20090518 \&$ tipo=5\&formato=PDF $>$. Acesso em 19 jan. 2019.

BRASIL. Supremo Tribunal Federal. Habeas Corpus n. 94.397. Rel. Min. Cézar Peluso. DJe 23.04.2010. Brasília, DF, 9 mar. 2010a. Disponível em: <http://redir. stf.jus.br/paginadorpub/paginador.jsp?docTP=AC\&docID=610170>. Acesso em 8 abr. 2019.

BRASIL. Superior Tribunal de Justiça. Habeas Corpus n. 150.032/MG. Rel. Min. Jorge Mussi, DJe 13.09.2010. Brasília, DF, 2010b. Disponível em: <https://ww2. stj.jus.br/processo/revista/documento/mediado/?componente=ATC\&sequen- 
cial $=16460098 \&$ num_registro $=200901973419 \&$ data $=20110829 \&$ tipo $=51 \&-$ formato=PDF $>$. Acesso em: 19 jan. 2019.

BRASIL. Decreto n. 8.935, de 19 de dezembro de 2016. Altera o Decreto n. 5.123, de $1^{\circ}$ de julho de 2004 , que regulamenta a Lei n. 10.826, de 22 de dezembro de 2003, que dispóe sobre registro, posse e comercialização de armas de fogo e munição, sobre o Sistema Nacional de Armas - SINARM e define crimes. Disponível em: <http://www.planalto.gov.br/ccivil_03/_Ato2015-2018/2016/Decreto/ D8935.htm>. Acesso em: 18 fev. 2019.

BRASIL. Decreto n. 9.685, de 15 de janeiro de 2019. Altera o Decreto n. 5.123, de $1^{\circ}$ de julho de 2004, que regulamenta a Lei n. 10.826, de 22 de dezembro de 2003, que dispõe sobre registro, posse e comercialização de armas de fogo e munição, sobre o Sistema Nacional de Armas - SINARM e define crimes. Disponível em: <http://www.planalto.gov.br/ccivil_03/_Ato2019-2022/2019/Decreto/ D9685.htm>. Acesso em: 18 fev. 2019.

GARCIA-PABlOS DE MOLINA, A.; GOMES, L. F. Direito Penal. Parte Geral. v. 2. São Paulo: Revista dos Tribunais, 2007.

GATTA, G. L. Abolitio Criminis e successione di norme integratrici: teoria e prassi. Milano: Giuffrè, 2008.

GUARAGNI, F.; BACH, M. Norma penal em branco e técnicas de reenvio em Direito Penal. São Paulo: Almedina, 2014.

HORTA, F. G. A. Do erro sobre os elementos em branco das leis penais: uma análise a partir do Direito Socioeconômico brasileiro. Tese (Doutorado) Programa de Pós-graduação, Faculdade de Direito, Universidade Federal de Minas Gerais, Belo Horizonte, 2012.

LUISI, L. Os Princípios Constitucionais Penais. 2. ed. Porto Alegre: Sergio Antônio Fabris, 2003.

MARINUCCI, G.; DOLCINI, E. Manuale di Diretto Penale. 4. ed. Milano: Giuffrè, 2012.

MENDONÇA, T. M. C. Lei Penal em Branco: um confronto com o princípio da legalidade e análise dos crimes ambientais e econômicos. Rio de Janeiro: Lumen Juris, 2016.

PIERANGELI, J. H. Escritos jurídicos-penais. 3. ed. São Paulo: Revista dos Tribunais, 2006. 
SILVA SANCHEZ. J.-M. Legislación penal socio-económica e retroactividad de la disposicione favorables: el caso de la leyes en blanco. Madrid, 1992. Disponível em: <http://dspace.usc.es/bitstream/10347/4191/1/pg_423-466_penales16.pdf>. Acesso em: 1 nov. 2015.

WELZEL, H. Derecho Penal: parte general. Buenos Aires: Roque Depalma, 1956. 